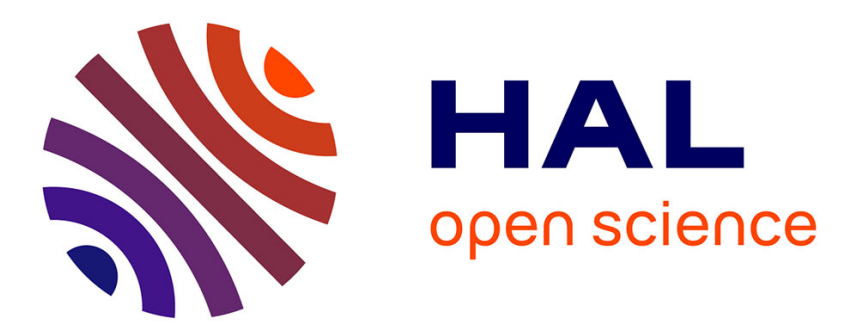

\title{
Large-scale spatial heterogeneity of macrozooplankton in Lake of Geneva
}

\author{
Bernadette Pinel-Alloul, Catherine Guay, Nadine Angeli, Pierre Legendre, \\ Pierre Dutilleul, Gérard Balvay, Daniel Gerdeaux, Jean Guillard
}

\section{- To cite this version:}

Bernadette Pinel-Alloul, Catherine Guay, Nadine Angeli, Pierre Legendre, Pierre Dutilleul, et al.. Large-scale spatial heterogeneity of macrozooplankton in Lake of Geneva. Canadian Journal of Fisheries and Aquatic Sciences, 1999. hal-03043300

\section{HAL Id: hal-03043300 https: / hal.inrae.fr/hal-03043300}

Submitted on 7 Dec 2020

HAL is a multi-disciplinary open access archive for the deposit and dissemination of scientific research documents, whether they are published or not. The documents may come from teaching and research institutions in France or abroad, or from public or private research centers.
L'archive ouverte pluridisciplinaire HAL, est destinée au dépôt et à la diffusion de documents scientifiques de niveau recherche, publiés ou non, émanant des établissements d'enseignement et de recherche français ou étrangers, des laboratoires publics ou privés. 


\title{
Large-scale spatial heterogeneity of macrozooplankton in Lake of Geneva
}

\author{
Bernadette Pinel-Alloul, Catherine Guay, Nadine Angeli, Pierre Legendre, \\ Pierre Dutilleul, Gérard Balvay, Daniel Gerdeaux, and Jean Guillard
}

\begin{abstract}
Spatial distribution of macrozooplankton was studied during spring in Lake of Geneva to evaluate the influence of abiotic (water temperature and stability, nutrients) and biotic (bacteria, chlorophyll $a$, fish biomass) factors on macrozooplankton distribution. Mapping and spatial analyses revealed that abiotic factors, as well as crustacean abundances, were structured along a gradient in the great lake basin. Chlorophyll $a$ biomass, bacteria density, cyclopoid abundance, and fish biomass showed more patchy or inshore-offshore distribution patterns. Using canonical analyses, we determined the relative contribution of the spatial and environmental factors to the distribution of macrozooplankton species and of trophic groups based on herbivory and omnivory/carnivory. The distribution of macrozooplankton can be explained by small-scale variations and lake gradients in abiotic and biotic factors, with a dominant contribution of the abiotic factors. Water temperature and stability, as well as ammonium, are the main factors related to macrozooplankton distribution in Lake of Geneva during spring. Chlorophyll $a$ biomass was also related to the distribution of cyclopoids. The canonical models explained $35-72 \%$ of the variance in the distribution of total crustaceans, species, and trophic groups. However, 28-65\% of the macrozooplankton variance remained unexplained, which may be due to fine-scale variations in other environmental factors.
\end{abstract}

Résumé : La distribution spatiale du macrozooplancton dans le Lac Léman (ou Lac de Genève) a été étudiée au printemps pour déterminer l'influence des facteurs abiotiques (température et stabilité de la colonne d'eau, nutriments) et biotiques (bactéries, chlorophylle $a$, biomasse des poissons) sur la distribution du macrozooplancton. La cartographie et l'analyse spatiale ont révélé que les facteurs abiotiques, ainsi que l'abondance des crustacés, étaient structurés selon un gradient dans le grand lac. La biomasse en chlorophylle $a$, la densité des bactéries, l'abondance des cyclopoïdes et les biomasses de poissons présentaient des patrons de distribution plus agrégés ou des gradients rive-large. À l'aide d'analyses canoniques, nous avons évalué l'influence relative des facteurs environnementaux et des structures spatiales dans la distribution des espèces de macrozooplancton et des groupes trophiques basés sur les catégories d'herbivores et d'omnivores/carnivores. La distribution du macrozooplancton s'explique à la fois par les variations locales à petite échelle et les gradients à grande échelle des facteurs abiotiques et biotiques, avec une contribution plus importante des facteurs abiotiques. La température et la stabilité de la masse d'eau ainsi que les concentrations en ammoniaque sont les principaux facteurs reliés à la distribution spatiale du macrozooplancton dans le grand basin du Lac de Genève. La biomasse en chlorophylle $a$ est aussi reliée à la répartition des cyclopoïdes. Les modèles canoniques expliquent 35 à $72 \%$ de la variabilité dans la distribution des crustacés totaux, des espèces et des groupes trophiques. Toutefois, de 28 à $65 \%$ de la variance du macrozooplancton reste inexpliqué, ce qui pourrait être imputable aux variations à petite échelle d'autres facteurs environnementaux.

\section{Introduction}

Zooplankton patchiness occurs on a continuum of scales in both marine and freshwater environments; zooplankton spatial heterogeneity is the product of the interaction of physical and biological processes (Pinel-Alloul 1995). De- spite the importance of spatial heterogeneity for ecological theory (Hastings 1990; Bell et al. 1993; Legendre 1993) and zooplankton ecology (Pinel-Alloul et al. 1995; Megard et al. 1997), studies of distribution patterns of zooplankton in large lakes, and of their plausible causes, are yet limited. Very few studies have been carried out at the whole-lake

Received August 6, 1998. Accepted February 10, 1999.

$\mathrm{J} 14734$

B. Pinel-Alloul, ${ }^{1}$ C. Guay, and P. Legendre. GRIL, Groupe de Recherche Interuniversitaire en Limnologie et en Environnement Aquatique, Département de Sciences biologiques, Université de Montréal, C.P. 6128, Succ. Centre-ville, Montréal, QC H3C 3J7, Canada.

N. Angeli, G. Balvay, D. Gerdeaux, and J. Guillard. Station d'Hydrobiologie lacustre, INRA, B.P. 511, 74203 Thonon-les-Bains Cedex, France.

P. Dutilleul. Department of Plant Science, Faculty of Agricultural and Environmental Sciences, Macdonald Campus, McGill University, 21111 Lakeshore Road, Sainte-Anne-de-Bellevue, QC H9X 3V9, Canada.

${ }^{1}$ Author to whom all correspondence should be addressed. e-mail: pinelb@ere.umontreal.ca 
scale in large tropical and temperate lakes (Hart 1990; Patalas and Salki 1992; Holopainen et al. 1993; Viljanen and Karjalainen 1993) and none in large alpine lakes.

Recent studies have provided evidence that many factors may be responsible for the spatial heterogeneity of lake zooplankton: wind (Jones et al. 1995) and wind-induced currents (Lacroix and Lescher-Moutoué 1995), water temperature (Betsill and van den Avyle 1994) and inshore-offshore thermic gradients (Johannsson et al. 1991; Stockwell and Sprules 1995), size of zooplankton, swimming capacity, and avoidance behaviour (Pinel-Alloul et al. 1988; Visman et al. 1994), spatial scale of the observations (Pinel-Alloul and Pont 1991; Lacroix and Lescher-Moutoué 1995), food resources (Johannsson et al. 1991; Pourriot et al. 1994), fish predation (Johannsson et al. 1991; De Meester et al. 1993; Viljanen and Karjalainen 1993), and lake morphometry (Patalas and Salki 1992), among others. It is presently recognized that abiotic factors alone are not sufficient to satisfactorily explain the spatial variability of zooplankton (Pinel-Alloul et al. 1990, 1995). This variability may also be studied under a model of biotic interactions among the planktonic compartments (McQueen et al. 1986; Northcote 1988; Vanni 1988; Carpenter and Kitchell 1993). Hence, the plankton community is a dynamic system. Understanding it requires a combination of abiotic and biotic explanatory factors in order to reach more realistic and reliable predictions about its ecology (Carpenter 1988; Mazumder et al. 1988).

Results of an extensive whole-lake sampling program, carried out in Lake of Geneva (Lac Léman in France) in mid-April 1985, were used to study the horizontal spatial heterogeneity of macrozooplankton during the spring using geostatistical and canonical methods of analysis. We chose Lake of Geneva because it is a large alpine lake with horizontal current dynamics (Lemmin 1989); thus, it should be clearly spatially structured, presenting patches and gradients in the abiotic and biotic factors and in the zooplankton community as well (Angeli et al. 1991). This is the first wholelake study of zooplankton spatial distribution in a large alpine lake reported in the literature. Furthermore, no study has paid attention to the relationships between the horizontal distribution of macrozooplankton and environmental factors in large alpine lakes, where water movements and advective processes are important driving forces, especially during the spring, as in all large lakes.

In this study, the spatial heterogeneity in the environment and the macrozooplankton community was analysed in order to explain the horizontal distribution of macrozooplankton with respect to abiotic (water stability and temperature, nutrients) and biotic (bacteria, chlorophyll $a$, fish) environmental factors. Our contention was that spatial heterogeneity in the biotic and abiotic factors provides for different modes of functioning of the zooplankton community, generating spatial heterogeneity in zooplankton distribution. This conceptual scheme allowed us to focus on the following specific objectives and hypotheses: $(i)$ to verify that the crustacean planktonic community in Lake of Geneva presents horizontal patterns of distribution, during the spring, at the wholelake scale, (ii) to confirm that both the dependent (macrozooplankton) and independent (environmental) variables were spatially structured, (iii) to analyse the degree of correlation among the environmental variables and between the environmental and macrozooplankton variables, (iv) to measure the relative importance of the effects of the biotic and abiotic variables on the horizontal distribution of macrozooplankton, and $(v)$ to check whether the abiotic factors are the main factors explaining the distribution of macrozooplankton during the spring. Given the dominant role of zooplankton in the transfer of energy to roach, perch, and whitefish in alpine lakes (Angeli et al. 1995) during the spring, it is important to clearly understand and resolve how the interaction among temperature, nutrients, food, and fish predation may translate into spatial patterns of macrozooplankton distribution. Finally, we will attempt to untangle the effects of the abiotic and biotic variables on the macrozooplankton distribution in Lake of Geneva during the spring as a model for large European alpine lakes.

\section{Materials and methods}

\section{Study site and sampling}

Lake of Geneva $\left(46^{\circ} 27 \mathrm{~N} ; 6^{\circ} 32^{\prime} \mathrm{E}\right)$ is located partly in France $(40 \%)$ and partly in Switzerland $(60 \%)$ (Fig. 1). Its watershed covers $7975 \mathrm{~km}^{2}$. The Rhône, Dranse, Venoge, Veveyse, and Aubonne rivers are its major tributaries (Zahner 1984). The lake is $72 \mathrm{~km}$ long and 13-14 km wide. With a surface area of $582 \mathrm{~km}^{2}$, a mean depth of $153 \mathrm{~m}$ (maximum depth $309 \mathrm{~m}$ ), and a volume of $89 \mathrm{~km}^{3}$, Lake of Geneva is the largest subalpine lake in western Europe. Water retention time varies from 5 years for the surface layer to 20 years for deeper layers, with an average of 12 years (Pelletier and Blanc 1991). The lake consists of two basins: the "small lake" (the shallower and elongated western part near Geneva: mean depth $41 \mathrm{~m}$ ) and the "great lake" (the larger and deeper eastern part). The great lake, in turn, consists of three regions: the "upper lake" (easternmost part) at the Rhone inflow, the "middle lake" in front of Lausanne, and the "lower lake" (westernmost part) near Thonon. Lake of Geneva is a warm monomictic lake, which changed rapidly from being oligotrophic to mesotrophic during the 1960's and 1970's due to anthropogenic eutrophication (Pelletier and Blanc 1991).

Sampling took place during daytime on 17-19 April 1985 during the spring, a period of the year with strong northeasterly winds (Fig. 1). Short-term sampling over 3 days enabled us to minimize the temporal variation in zooplankton distribution. Zooplankton was sampled at 33 sites over the whole lake (Fig. 1). Distances between sites were almost regular, varying from 3 to $5 \mathrm{~km}$. Zooplankton samples were taken at each site by vertical filtration of $1900 \mathrm{~L}$ of water over the 0 - to 50-m water column, using a 55-cmwide, $175-\mu \mathrm{m}$-mesh biconical closing net (Asptein's type; Tranter 1968). The choice of the 0- to 50-m depth range for zooplankton sampling enabled us to avoid bias due to the vertical migrations of zooplankton, since most of the zooplankton is distributed only across the 0- to 50-m water layer during the diel cycle (Angeli et al. 1995). Water samples for chlorophyll $a$, bacteria, phosphate $\left(\mathrm{PO}_{4}\right)$, nitrate $\left(\mathrm{NO}_{3}\right)$, and ammonium $\left(\mathrm{NH}_{4}\right)$ measurements were integrated over the 0 - to $10-\mathrm{m}$ water column at each site using a patented integration bell that is based on Mariot's law; a previous study showed that peaks of chorophyll $a$ always occurred between 3 and $7 \mathrm{~m}$, and maximal primary production was situated in surface waters (2-5 m) (Balvay et al. 1985). A mean temperature was calculated for the 5- to $25-\mathrm{m}$ water layer that covers the thermic vertical gradient during the sampling period (Fig. 1). The surface layer $(0-5 \mathrm{~m})$ was excluded from the calculation of mean values of water temperature to avoid problems of daily variation (Angeli et al. 1991) 
Fig. 1. Bathymetric map of Lake of Geneva with its main affluents, different basins, and sampling stations (upper map), modified from Zahner (1984), wind speed recorded at each meteorological station (A, B, C, D) during the sampling survey (17-19 April) and the previous day (16 April) (map upper left corner), and temperature profiles at each sampling station (lower map).

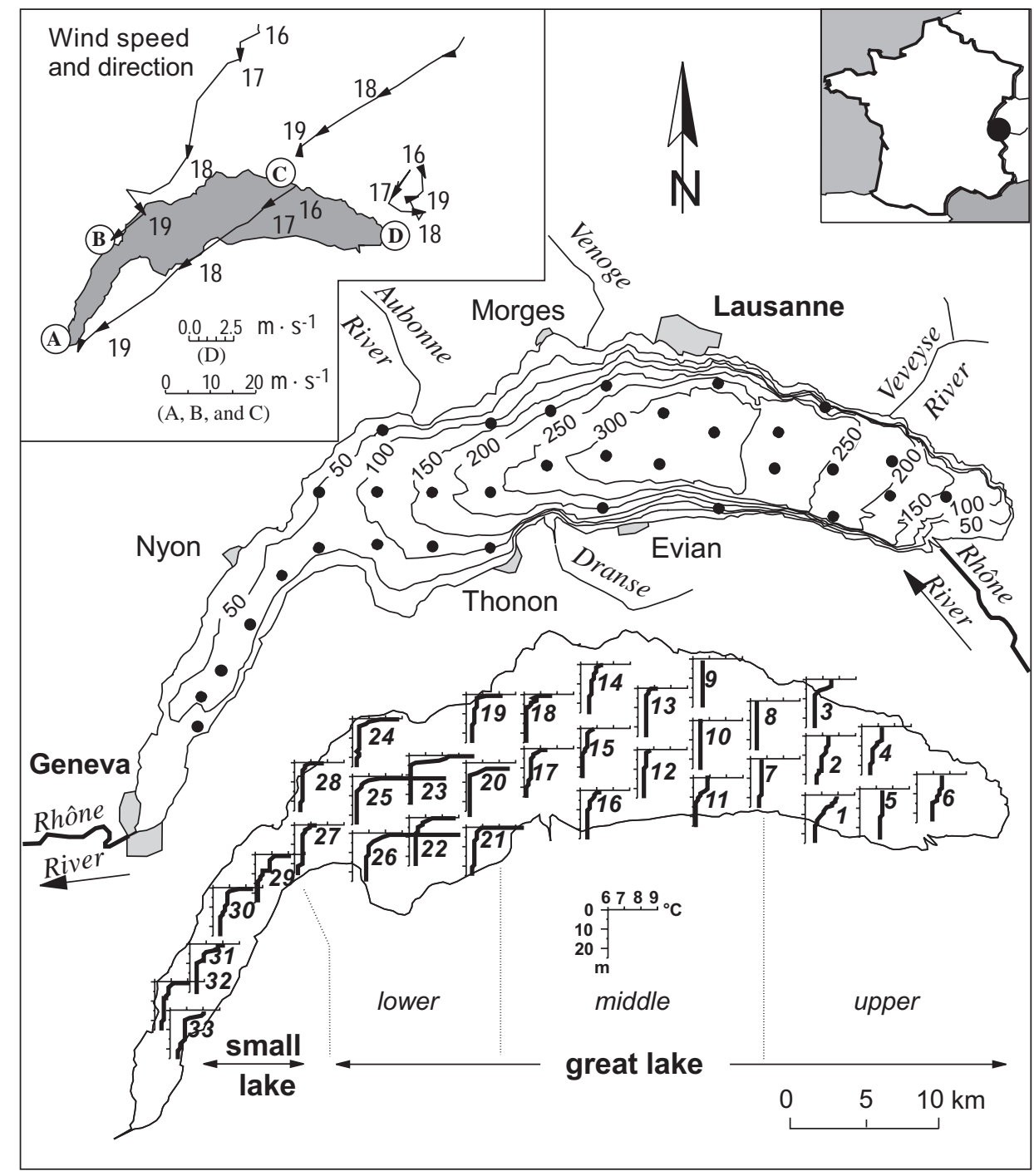

\section{Environmental and zooplankton variables}

Chlorophyll $a$ concentrations were measured using a Turner ${ }^{\mathrm{TM}}$ fluorometer after acetone extraction (Yentsch and Menzel 1963) and spectrophotometric calibration. Bacterial abundances were estimated using epifluorescence microscopy (magnification 1250×) after orange acridine staining (Hobbie et al. 1977). Concentrations of $\mathrm{NO}_{3}$ were obtained after conversion to nitrite by cadmium reduction following the method defined by the Association française de normalisation (AFNOR) and described in Gawler et al. (1986). $\mathrm{NH}_{4}$ concentrations were measured using the indophenol blue method following the AFNOR NFT90 015 norm (Koroleff 1970). $\mathrm{PO}_{4}$ concentrations were measured using the method of Murphy and Riley (1962).

The simplest practical method for estimating the intensity of mixing at each site was to characterize the vertical stability of the water column $\left(N^{2}\right)$ using the density difference $(\delta \rho / \delta z)$ over a given depth range (Reynolds 1984):

$$
N^{2}=(g / \rho)(\delta \rho / \delta z)
$$

where $g$ is the acceleration due to gravity (about $9.81 \mathrm{~m} \cdot \mathrm{s}^{-2}$ at $46^{\circ} \mathrm{N}$ ), $\rho$ is the water density (in kilograms per cubic metre), $z$ is the thickness (metres) of the layer, and $\delta \rho$ is the variation of water density across this layer. Water stability $\left(N^{2}\right)$ has the dimension of a frequency (per second squared); it is known as the Brunt-Väisälä frequency and represents one of the resonance modes of metalimnetic oscillations (Lemmin 1995). Vertical stability profiles were calculated from temperature profiles over the 5- to $15-\mathrm{m}$ depth range using a parabolic approximation (Imboden et al. 1979). The surface layer $(0-5 \mathrm{~m})$ was excluded from the calculation to avoid problems of daily variation (Angeli et al. 1991).

As an additional environmental variable, fish biomass was obtained from an echosounding survey concomitant with the synoptic zooplankton sampling program. Fish biomass was estimated by echointegration (20 $\log R$; see MacLennan and Simmons 1992) using a $70-\mathrm{kHz}$ SIMRAD sounder (model EY-M with a circular transducer, $11^{\circ}$ total beam angle at $-3 \mathrm{~dB}$ ). Echointegration transects were obtained for contiguous 10-min sequences over $800 \mathrm{~m}$. At each site, fish biomass was estimated from the original echointegration survey and averaged over two sequences: the one recorded just before arriving at a sampling site and the one just after the site. Fish biomass was evaluated over the whole water column in volts squared per square metre; this is proportional to the energy reflected by fish targets. During the spring, fish community 
in Lake of Geneva is dominated by planktivorous fish, mainly adults of roach (Rutilus rutilus) and whitefish (Coregonus laveratus) (Gerdeaux and Guillard 1986).

Identification of crustacean zooplankton was carried out on a subsample of each formaldehyde-fixed sample. Small representative subsamples (containing 100-300 individuals of the species and instars to be counted, as far as feasible) were prepared by dividing the original samples zero to five times using a Motoda box (Motoda 1959), depending on zooplankton density. Zooplankton crustaceans were counted according to species and ontogenic stages (nauplii and copepodites $\mathrm{C} 1$ of cyclopoids, nauplii of calanoids, copepodites $\mathrm{C} 1-\mathrm{C} 5$ of the calanoid species, copepodites C2-C5 of each cyclopoid species, adults of each cyclopoid and calanoid species, adults and juveniles of cladocerans) under a stereoscopic dissection microscope. We referred to Dussart $(1967,1969)$ for taxonomic identification of the copepods and to Flossner (1972) and Amoros (1984) for cladocerans. Zooplankton taxa were also categorized by trophic groups: small herbivores (nauplii, C1C3 of Eudiaptomus gracilis and cyclopoids, juvenile daphnids), large herbivores (C4, C5, and adults of E. gracilis, adult daphnids), and omnivores/carnivores (C4, C5, and adults of cyclopoids) (Gawler et al. 1988).

\section{Statistical methods}

Illustrations of whole-lake spatial distributions were obtained by mapping zooplankton abundances and environmental variables. Circles, whose area is proportional to the values to be represented, were plotted on maps of the lake (see Figs. 2 and 3).

Earlier observations conducted on the lake revealed that the small and great lakes have distinct thermal and nutrient regimes and different plankton distributions and seasonal dynamics (e.g., Balvay et al. 1984; Monod et al. 1984a, 1984b). This is supported by our observations (Fig. 2). Because most methods of spatial analysis require the data to be stationary over space (Cressie 1991), we decided to exclude the five sites of the small lake (sites 29-33, Fig. 1) from the following analyses.

The significance of spatial autocorrelation for individual variables was assessed using the Geary's $c$ autocorrelation statistics in spatial correlograms (Geary 1954). The variables should be normalized prior to spatial autocorrelation analysis (Sokal 1979). The Box-Cox transformation was used for normalization, using the form that also induces homogeneity of variances (Sokal and Rohlf 1995). Geary's $c$ coefficients were assembled in a correlogram for each taxon or variable (see Figs. 2 and 3). In each correlogram, we used distance classes with equal numbers of pairs so that even high distance classes would contain enough pairs to carry out tests of significance of the autocorrelation statistics (Legendre and Vaudor 1991; Legendre and Legendre 1998). Levels of significance were corrected to take multiple testing into account; for 10 simultaneous tests, we used $0.05 / 10=0.005$ as the corrected significance level (Bonferroni correction). Once the overall correlogram is significant based on the Bonferroni test, the shape of the spatial correlogram can be used to infer underlying ecological process affecting variable spatial patterning. For the ecological interpretation of spatial correlograms, see Legendre and Fortin (1989), Dutilleul and Legendre (1993), and Legendre and Legendre (1998).

To identify the spatial structures displayed by the multivariate tables of environmental variables, abundances of crustacean taxa, and trophic groups, Mantel correlograms were computed as a function of geographical distances (Oden and Sokal 1986; Legendre and Legendre 1998). Gower's coefficient of similarity was used to quantify the ressemblance among sites based on the environmental variables, while the Steinhaus coefficient was used for the zooplankton data (Legendre and Legendre 1998). A test of significance is attached to each statistic in a Mantel correlogram, just as in a Geary's $c$ autocorrelogram. All correlograms were computed using the R package of Legendre and Vaudor (1991).
Different methods have been proposed recently to assess the significance of the correlation between spatially autocorrelated variables (Clifford et al. 1989; Haining 1990, 1991; Dutilleul 1993; Dutilleul and Pinel-Alloul 1996). To determine the degrees of freedom of the $t$ test statistic, Clifford et al. (1989) and Dutilleul (1993) used an estimated effective sample size, which is a function of the autocorrelation (in sign and magnitude) present in both variables. In this study, we used Dutilleul's modification and the Spearman coefficient to compute the correlations among the environmental variables and between the zooplankton taxa and the environmental variables. A rank transformation was applied to all variables to avoid problems stemming from the nonnormality of their distributions and from the restricted (i.e., monotonic) nonlinearity of their relationships. Autocorrelation in Dutilleul's correction was estimated by $(1-c)$, with $c$ the Geary's coefficient computed from the original (not rank transformed) data.

To evaluate the relative importance of the spatial and environmental factors on the distribution of zooplankton, the total variation of the zooplankton taxa or trophic group matrices was partitioned into four components following Borcard et al. (1992) and Borcard and Legendre (1994): (i) the nonspatially structured environmental component (fraction a), representing the local effects of the environmental factors, (ii) the spatially structured component of the zooplankton variation (fraction b) that is shared by the independent environmental variables, which represents, for instance, environmental gradients, (iii) the spatial component of the zooplankton variation (fraction c) that is not shared by the environmental variables included in the analysis, and (iv) fraction $\mathrm{d}$ of undetermined (nonspatial) variation. The variance in the distribution of the macrocrustaceans (species vectors) and trophic groups (trophic group vectors) was partitioned using redundancy analysis (RDA) and partial RDA constrained by the spatial and environmental variables. RDA and partial RDA were computed using version 3.11 of the CANOCO program (ter Braak 1988, 1990). The matrix of independent environmental variables contained water temperature, water stability, concentrations of $\mathrm{PO}_{4}, \mathrm{NO}_{3}, \mathrm{NH}_{4}$, and chlorophyll $a$, bacteria, and fish biomass. We excluded the N/P ratio, which was strongly correlated with both $\mathrm{PO}_{4}$ and $\mathrm{NH}_{4}$, to avoid collinearity among the environmental variables (see Table 4). A forward selection procedure was applied to the environmental variables in each analysis.

Because the spatial patterns of the zooplankton distribution may be more complex than primary linear gradients, we used a geographic polynomial of the second degree, which better reflects the complexity of regional distributional patterns than linear gradients, as suggested by Legendre (1990):

$$
f(X, Y)=b_{0}+b_{1} X+b_{2} Y+b_{3} X^{2}+b_{4} X Y+b_{5} Y^{2}
$$

where $X$ and $Y$ are Cartesian longitude and latitude coordinates of the sampling sites centred on their respective means. In each analysis, a forward selection procedure was used to select the terms of eq. 2 that contributed significantly to the total explained variation of the response variables.

\section{Results}

\section{Macrozooplankton community and environmental variables}

Whole-lake spatial variation in the abundance of macrozooplankton species was important in Lake Geneva during the spring. Abundances of the crustacean species or stages varied by more than an order of magnitude across the lake, and coefficients of variation (\% CV in Table 1$)$ were higher than $50 \%$ (Table 1). The most abundant species were the calanoid E. gracilis ( $47 \%$ of total crustacean abundance) and 
Table 1. Mean, standard error of the mean, and range of abundance $\left(10^{3}\right.$ ind. $\left.\cdot \mathrm{m}^{-2}\right)$ of the total crustacean zooplankton, main species, and copepodite stages over the whole lake.

\begin{tabular}{llrrrrr}
\hline Zooplankton species & Stage & Mean & SE & Maximum & Minimum & $\%$ CV \\
\hline Crustacean zooplankton & & 1562 & 812 & 3469 & 426 & 52 \\
Eudiaptomus gracilis & Adults & 256 & 136 & 662 & 78 & 53 \\
& C5 & 161 & 98 & 432 & 24 & 61 \\
& C4 & 110 & 64 & 310 & 21 & 58 \\
& C1-C3 & 216 & 148 & 778 & 42 & 68 \\
Cyclops vicinus & Adults & 184 & 187 & 667 & 11 & 102 \\
& C5 & 26 & 22 & 80 & 2 & 87 \\
& C4 & 26 & 23 & 99 & 3 & 88 \\
Cyclops prealpinus & C2 and C3 & 38 & 37 & 157 & 4 & 98 \\
& Adults & 18 & 15 & 58 & 0 & 84 \\
& C5 & 19 & 16 & 69 & 2 & 86 \\
Copepodite cyclopoids & C4 & 28 & 20 & 99 & 4 & 73 \\
Nauplii & C2 and C3 & 116 & 95 & 438 & 12 & 82 \\
Daphnia hyalina & Calanoids & 127 & 69 & 331 & 25 & 61 \\
& Cyclopoids & 164 & 92 & 349 & 41 & 54 \\
& Adults & 14 & 12 & 59 & 2 & 56 \\
\hline
\end{tabular}

Note: C5, copepodite 5; C4, copepodite 4; C1-C3, copepodites 1, 2, and 3 pooled; C2 and C3, copepodite, 2 and 3 pooled; $\mathrm{C} 1$, copepodite 1 .

Table 2. Mean, standard error of the mean, and range of values of the abiotic (physical and chemical) and biotic environmental variables used as independent variables.

\begin{tabular}{|c|c|c|c|c|c|}
\hline Environmental variable & Mean & SE & Maximum & Minimum & $\% \mathrm{CV}$ \\
\hline \multicolumn{6}{|l|}{ Abiotic } \\
\hline Water temperature $\left({ }^{\circ} \mathrm{C}\right)$ & 6.38 & 0.23 & 7.04 & 5.93 & 4 \\
\hline Water stability $\left(\mathrm{s}^{-2}\right)$ & 0.2 & 0.36 & 1.7 & 0.0 & 160 \\
\hline $\mathrm{PO}_{4}\left(\mu \mathrm{g} \cdot \mathrm{L}^{-1}\right)$ & 65 & 4.1 & 74 & 57 & 6 \\
\hline $\mathrm{NO}_{3}\left(\mu \mathrm{g} \cdot \mathrm{L}^{-1}\right)$ & 544 & 12.6 & 570 & 520 & 2 \\
\hline $\mathrm{NH}_{4}\left(\mu \mathrm{g} \cdot \mathrm{L}^{-1}\right)$ & 7.8 & 7.0 & 32 & 1 & 90 \\
\hline $\mathrm{N} / \mathrm{P}$ & 8.5 & 0.5 & 9.4 & 7.5 & 6 \\
\hline \multicolumn{6}{|l|}{ Biotic } \\
\hline Chlorophyll $a\left(\mu \mathrm{g} \cdot \mathrm{L}^{-1}\right)$ & 1.6 & 0.5 & 3.3 & 0.8 & 32 \\
\hline Bacteria $\left(10^{6}\right.$ cells $\left.\cdot \mathrm{mL}^{-1}\right)$ & 1.1 & 0.4 & 2.7 & 0.1 & 39 \\
\hline Fish biomass $\left(\mathrm{V} \cdot \mathrm{m}^{-2}\right)$ & 1548 & 2911 & 10000 & 0 & 188 \\
\hline
\end{tabular}

two cyclopoid species: Cyclops vicinus (17\%) and Cyclops prealpinus (12\%). Copepodites $\mathrm{C} 1$ of $C$. prealpinus and C. vicinus, which could not be separated easily, were grouped. C1 stages represented, on average, only $4 \%$ of the total abundance of crustaceans, whereas nauplii of calanoids and cyclopoids represented about 8 and $10 \%$, respectively, of the total abundances. Among the cladocerans, Daphnia hyalina was the most important species but only represented $1.6 \%$ of the total crustaceans. Individuals of other species (Daphnia galeata, Daphnia longispina, Bosmina longirostris, and Acanthocyclops robustus) were too rare to be included in the analyses. Bythotrephes longimanus and Leptodora kindtii, both of which prey on zooplankton, were rare and encountered only as eggs and embryos during this spring sampling.

Information concerning the environmental variables are assembled in Table 2. Water was cold during the study period; temperature ranged from 5.9 to $7^{\circ} \mathrm{C}$. Although the temperature of surface waters was sometimes higher in the stations of the small and lower great lakes, temperature profiles (Fig. 1) generally indicated higher temperature $\left(>7^{\circ} \mathrm{C}\right)$ over the 0 - to $25-\mathrm{m}$ depth range in most stations of the upper great lake. The high concentrations of $\mathrm{PO}_{4}$ and $\mathrm{NO}_{3}$ (on average 65 and $544 \mu \mathrm{g} \cdot \mathrm{L}^{-1}$, respectively) reflected the important spring nutrient loading from the drainage basin. $\mathrm{PO}_{4}$, $\mathrm{NO}_{3}$, and the N/P ratio were relatively invariable, with CV's under $6 \%$. By contrast, stability of the $5-15 \mathrm{~m}$ water layer, as well as $\mathrm{NH}_{4}$ concentrations, varied greatly among sites (CV > 90\%). The biotic variables were moderately heterogeneous and showed low mean values: $1.6 \mu \mathrm{g}$ chlorophyll $a \cdot \mathrm{L}^{-1}$ and $1.1 \times 10^{6}$ bacteria. $\mathrm{mL}^{-1}$. In contrast, fish biomass was very heterogeneous across the lake; it had the highest $\mathrm{CV}$ of all explanatory variables.

\section{Mapping and spatial horizontal patterns}

Fairly consistent spatial patterns were observed in the distributions of macrozooplankton, when expressed as percentages of maximum abundances (Fig. 2). The general trend was an accumulation of crustaceans along the northeastern shore of the upper great lake. The pelagic zone, particularly in the middle and lower great lakes, as well as the southeast- 
Fig. 2. Distribution patterns of the crustacean species densities (left) and their respective autocorrelograms over the great lake (right). Vertical axis: Geary's $c$ autocorrelation coefficients; horizontal axis: distances expressed as ranked classes and $\mathrm{km}$ (mean value of the distances in the class). Solid squares are values significant at $\alpha^{\prime}=0.005$, open squares with a small solid square inside are values significant at $\alpha=0.05$, and white circles are nonsignificant values. Values of Geary's $c$ coefficients between 0 and 1 indicate positive autocorrelation; values higher than 1 indicate negative autocorrelation.

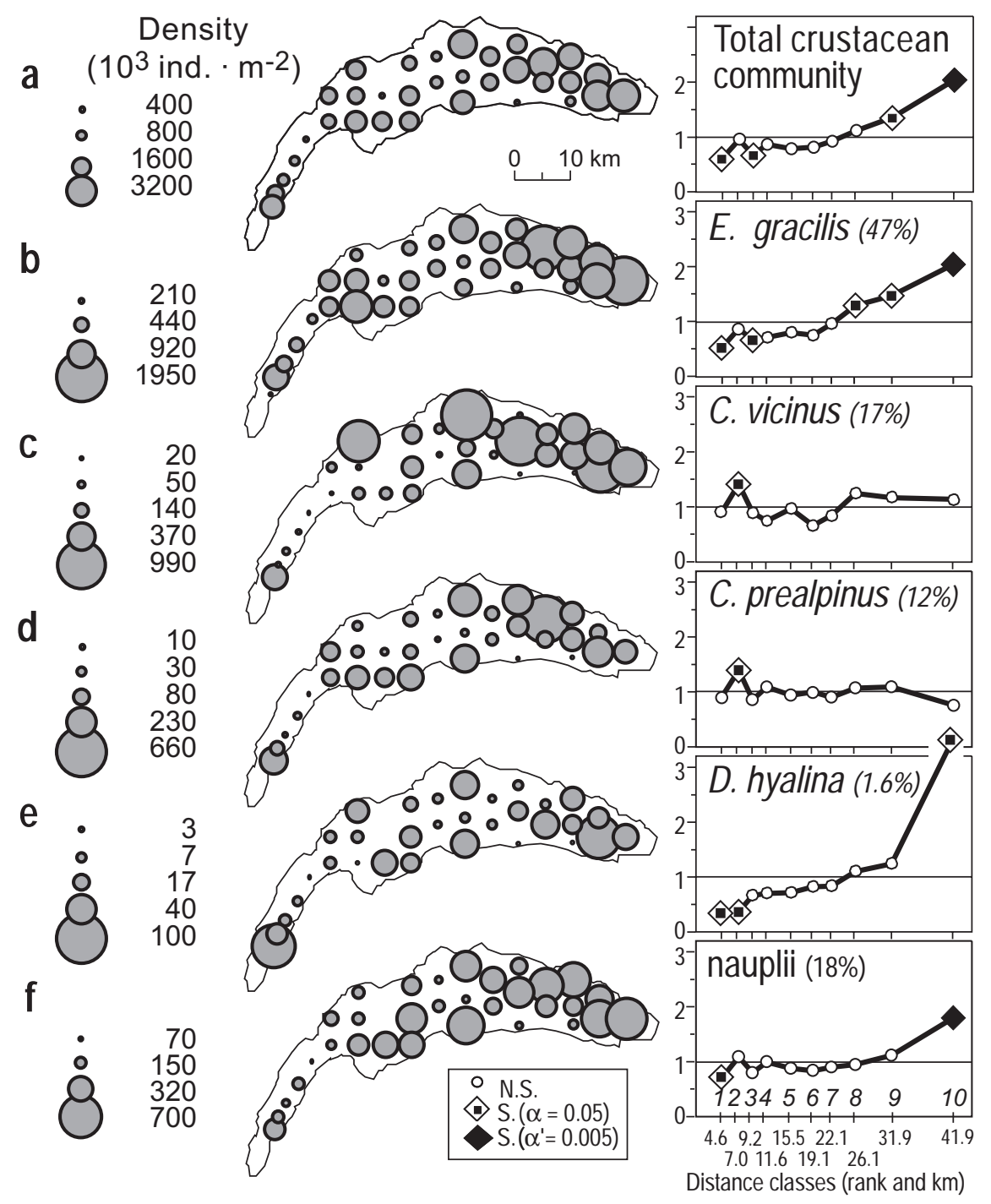

ern shore had low abundances. Abundances were low in the small lake, except at the last sampling site near Geneva.

Results of spatial autocorrelation analysis (Geary's $c$ correlograms, Fig. 2) supported the impression of spatial gradients given by the maps (positive spatial autocorrelation at small distances following by negative spatial autocorrelation at large distances). Since data from the small lake were not included in the analyses, the correlograms only reflect the spatial distribution of macrozooplankton in the great lake. For total abundances of crustaceans and the abundances of E. gracilis, there was weak positive autocorrelation among neighbouring sites (distance classes 1-3: 4.6$9.2 \mathrm{~km}$ ) and stronger negative autocorrelation at larger distances (classes 9 and 10: 31.9-41.9 km). Because E. gracilis accounted for most of the crustacean populations, the spatial distribution of E. gracilis in general (Fig. 2), and of its adults and C4 and C5 stages in particular (Table 3), was similar to that of the total abundance of macrozooplankton.
The younger copepodite stages $(\mathrm{C} 1-\mathrm{C} 3)$ and nauplii of calanoids also showed negative autocorrelation at large distances (Table 3). The abundances of $C$. vicinus appeared spatially independent, but the abundances of its C2 and C3 stages followed the same trend as the crustacean abundances with positive autocorrelation at intermediate (distance class 5: $15.5 \mathrm{~km}$ ) and negative autocorrelation at large distances (distance class 10: $41.9 \mathrm{~km}$ ) (Table 3). The correlogram of C. prealpinus reflected mostly the small-scale patchy distribution of its omnivorous/carnivorous older stages (adults and $\mathrm{C} 4$ and C5) at short distance (classes 2 and 3: 7.0 and $9.2 \mathrm{~km}$ ) (Fig. 2; Table 3). The distribution of D. hyalina followed that of the crustacean community with weak smallscale and large-scale autocorrelation (Fig. 2; Table 3). The distribution of nauplii and $\mathrm{C} 1$ of cyclopoids followed a similar trend to that of the total crustaceans (Fig. 2; Table 3).

A glance at the maps (Fig. 3) reveals that most environmental variables presented a gradient-like distribution over 


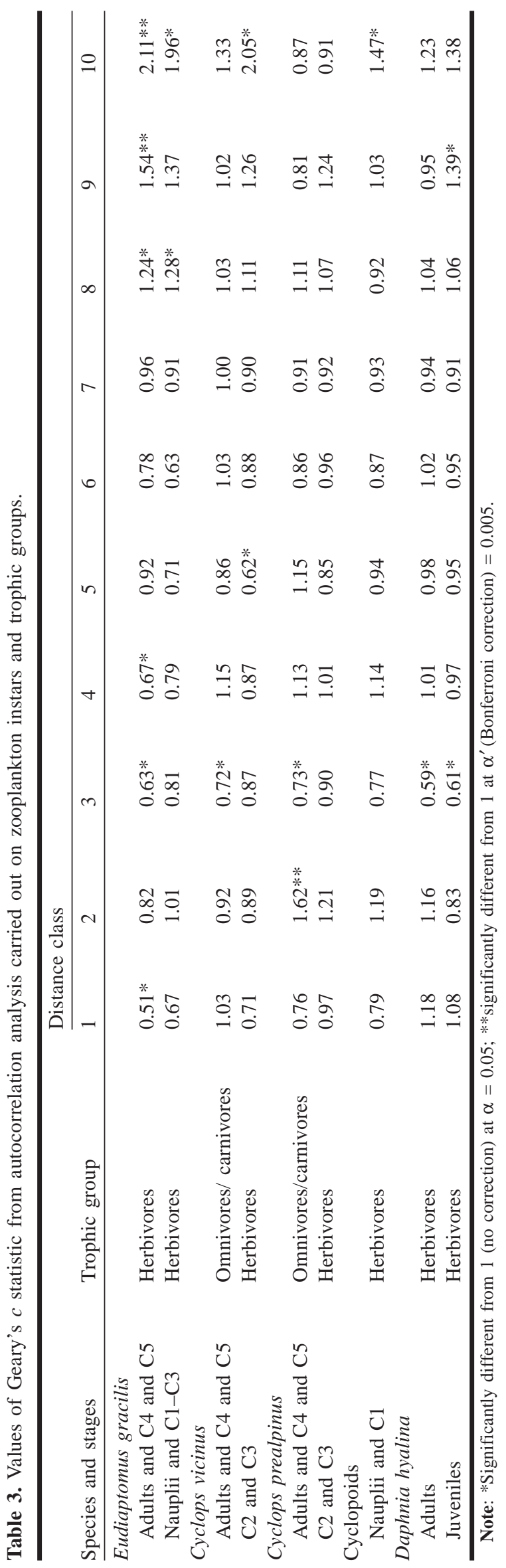

the great lake. The autocorrelograms supported the hypothesis that the abiotic environmental variables were indeed distributed along a gradient in the great lake basin (for interpretation of correlograms, see Materials and methods and Legendre and Fortin 1989). The highest temperatures were observed in the upper great lake. Positive autocorrelation occurred at short distance (classes 1-3: 4.9-9.2 km) and negative autocorrelation at large distances (classes 8-10: $26.1-41.9 \mathrm{~km}$ ). The spatial distribution of water stability values was similar to but weaker than that of temperature and $\mathrm{NH}_{4}$ and the opposite of that of $\mathrm{PO}_{4}$ and $\mathrm{NO}_{3}$. The highest concentrations of $\mathrm{NH}_{4}$ were measured in the upper great lake. The distributions of $\mathrm{PO}_{4}$ and $\mathrm{NO}_{3}$ concentrations formed strong inverse gradients with higher concentrations in the middle and lower great lakes (Fig. 3). These variables were positively autocorrelated at short distances (classes 15: $4.6-15.5 \mathrm{~km}$ ) and negatively autocorrelated at large distances (classes 8-10: 26.1-41.9 km). The spatial distribution of the N/P ratio was inversely related to that of $\mathrm{PO}_{4}$ and $\mathrm{NO}_{3}$ concentrations and positively to that of $\mathrm{NH}_{4}$ concentrations (Fig. 3).

The biotic variables have weaker spatial distributions than the abiotic variables (Fig. 3). Distribution patterns of chlorophyll $a$ and bacteria show the presence of higher concentrations in the small lake and at the eastern end of the great lake. Values were positively autocorrelated at short distances (class 1: $4.6 \mathrm{~km}$ for chlorophyll $a$; classes 2 and 3: 7.0 $9.2 \mathrm{~km}$ for bacteria) and negatively at large (class 9: $31.9 \mathrm{~km}$ for chlorophyll $a$ ) or intermediate distances (classes 5 and 7: 15.5 and $22.1 \mathrm{~km}$ for bacteria). The highest concentrations of chlorophyll $a$ and bacteria were in the eastern end of the upper lake, an area that had lower concentrations of $\mathrm{PO}_{4}$ and $\mathrm{NO}_{3}$. The whole data set collected for fish biomass during the acoustic survey (Fig. 3, small map with black circles over the range of $0-20000$; modified from Gerdeaux and Guillard 1986) showed strong spatial heterogeneity with much lower fish biomass in the cooler part of the lower lake and, in most places, with very steep inshore-offshore gradients, except in a limited area of the middle lake where an opposite trend (higher fish biomass offshore than inshore) was observed. The map of the data set subsampled from the acoustic survey for the same sites as the abiotic and biotic variables (Fig. 3, small map with black circles over the range $0-10000$ ) only weakly reflects the inshore-offshore gradient of fish biomass. The values of Geary's $c$, obtained using site-specific fish biomass data, did not indicate autocorrelation (Fig. 3).

The Mantel correlograms give a composite view of the spatial heterogeneity of the environmental and macrozooplankton variables (Fig. 4). They show that the values of the environmental variables were generally positively correlated $(r>0)$ at short distance (classes 1-3: 4.6-9.2 km) and negatively correlated $(r<0)$ at larger distances (distance classes 8-10: 26.1-41.9 km). This supports the hypothesis that the environmental variables formed a smooth large-scale gradient over the great lake $(50 \mathrm{~km})$. By contrast, the species and trophic groups may have formed patches at short distances, but their distributions did not display significant large-scale spatial patterns (Fig. 4).

Most of the relationships suspected from mapping over the great lake were found to be statistically significant (Ta- 
Fig. 3. Distribution patterns of values of the environmental variables (left) and their respective autocorrelograms over the great lake (right). See caption to Fig. 2 for a description of the correlograms. Two maps are presented for fish biomass: the small map corresponds to the whole acoustic survey and the large map shows the sites where other abiotic and biotic factors were measured.

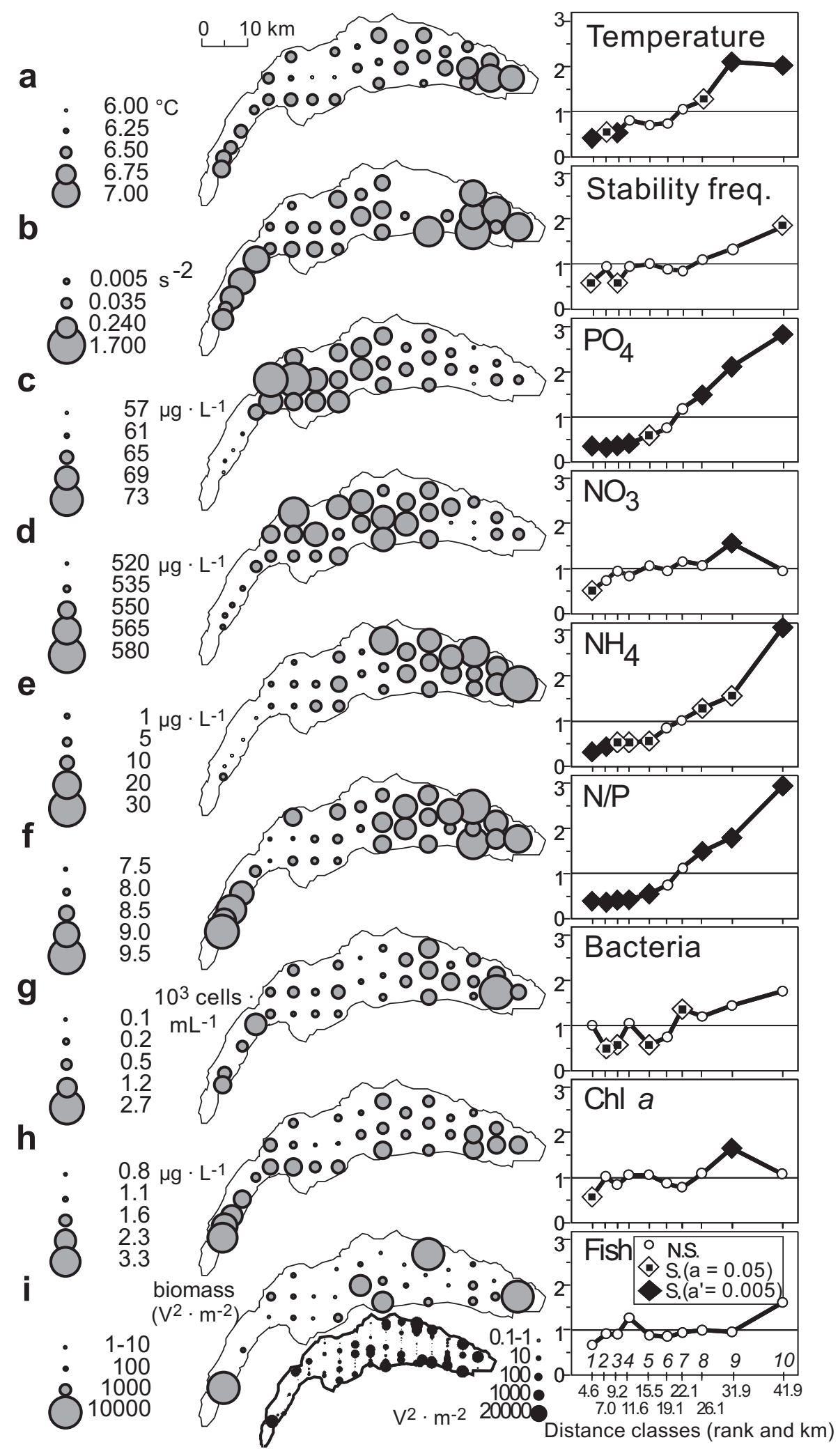


Fig. 4. Mantel correlograms for environmental variables (Env.), crustacean species (Sp.), and trophic groups (T.g.) based on their spatial distribution in the great lake. Vertical axis: values of Mantel's $r$; horizontal axis: distances expressed as ranked classes and $\mathrm{km}$ (mean value of the distances in the class). Solid circles circles are values significant at $\alpha^{\prime}=0.005$, open circles with a small solid circle inside are values significant at $\alpha=0.05$, and small solid circles are nonsignificant values.

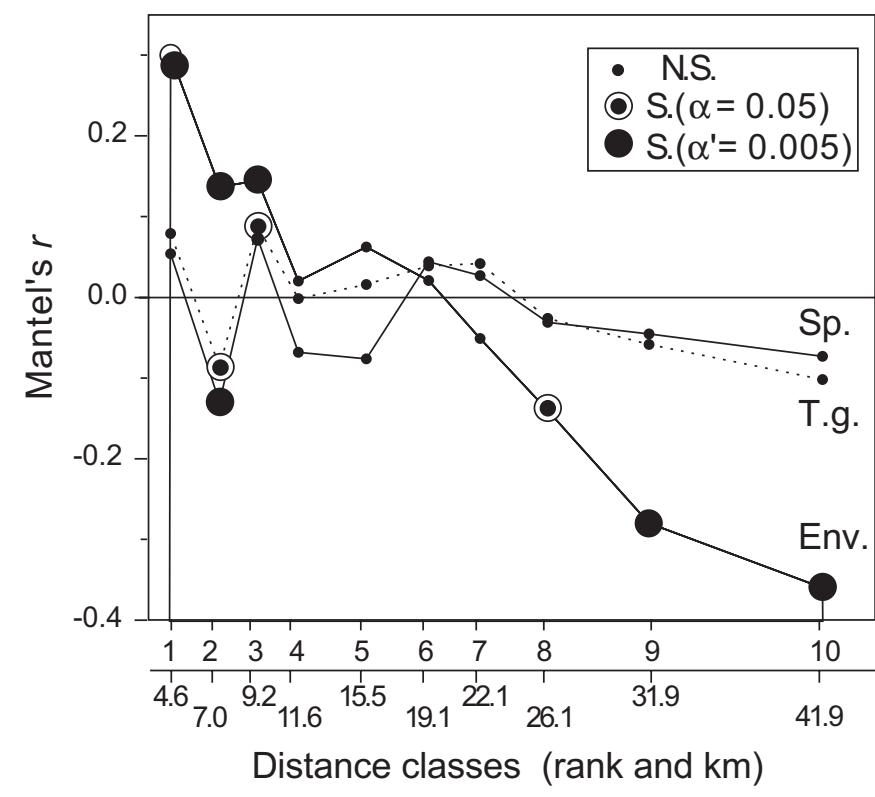

ble 4). No variable other than water temperature was linked, positively or negatively, to both the abiotic and biotic variables. Water temperature was positively correlated with $\mathrm{NH}_{4}$ and chlorophyll $a$ concentrations and negatively with $\mathrm{PO}_{4}$ and $\mathrm{NO}_{3}$. Water stability was inversely related to $\mathrm{NO}_{3}$ concentrations. $\mathrm{PO}_{4}$ showed a strong negative relationship with the $\mathrm{N} / \mathrm{P}$ ratio and $\mathrm{NH}_{4}$. Positive correlations with $\mathrm{NH}_{4}$ were detected for water temperature, the N/P ratio, and bacteria, whereas a negative correlation occurred with $\mathrm{PO}_{4}$. Chlorophyll $a$ concentrations were positively related to water temperature and fish biomass and negatively to $\mathrm{NO}_{3}$.

Abundances of total crustaceans, as well as most species and stages, were positively correlated with water temperature and $\mathrm{NH}_{4}$ (Table 5). In addition, the total abundances of C. prealpinus and of its $\mathrm{C} 2$ and $\mathrm{C} 3$ stages were significantly correlated with chlorophyll a concentrations. Cyclops vicinus (adults, C4 and C5) were positively correlated with the N/P ratio and the abundances of bacteria. Several species (C. vicinus, E. gracilis, and D. hyalina) and their juvenile or copepodite stages were inversely correlated with $\mathrm{PO}_{4}$ and (or) $\mathrm{NO}_{3}$. No significant correlations were found between water stability or fish biomass and macrocrustaceans.

\section{Variance partitioning}

Results from RDA and partial RDA showed that local variations in the environment (fraction a: local environmental effects) and the environmental gradients (fraction b: spatially structured environment) explained $71 \%$ of the total variation in the distribution of total macrocrustacean abundances (Table 6). Together, $\mathrm{NH}_{4}$ concentrations, water temperature, and water stability were the best explanatory variables of this distribution. Unexplained spatial effects (fraction c: space) were minor and explained less than $1 \%$ of the macrocrustacean distribution over the great lake. The relative importance of the local (fraction a) and spatially structured environmental components (fraction b) varied among species. The environmental components (fractions a and b) accounted for about $54 \%$ of the total variation in the abundances of E. gracilis and C. prealpinus and 29 and $38 \%$ of that of $C$. vicinus and D. hyalina, respectively (Table 6). The spatially structured environmental effects (fraction b) accounted for 60,100 , and $100 \%$ of the total explained variation (fractions a, b, and c) of E. gracilis, C. prealpinus, and $D$. hyalina abundances, respectively, while 60 and $43 \%$ of the explained variance (fractions a, b, and c) in the distribution of $C$. vicinus and nauplii abundances, respectively, could be attributable to the local environmental effects (fraction a). $\mathrm{NH}_{4}$ was systematically selected during the forward selection of explanatory variables (in many cases, it was the only variable selected) and was responsible for $39-84 \%$ of the explained variation in any species vector. Additional environmental variables were occasionally retained: water temperature, water stability, and chlorophyll $a$ concentrations. The best spatial variables retained to describe the distribution of the environmental factors were $X$ and $X^{2}$, corresponding to a longitudinal (east-west) gradient. Relatively little spatial effects (fraction c: 0-11\%) remained unexplained. The same can be said about the results for vectors of trophic groups (Table 7); the environmental components (fractions a and b) explained about $52-65 \%$ of the variation for the two herbivore vectors but only $43 \%$ of that of the omnivore/ carnivore vector. Between 28 and $65 \%$ of the total variation in the distribution of species and trophic groups remained unexplained (Tables 6 and 7).

\section{Discussion}

Spatial patterns of environmental factors

The gradient-like distribution of the abiotic variables suggests the action of some underlying nonrandom process contributing to the large-scale spatial structuring of the abiotic environment in the great basin of Lake of Geneva during the spring of 1985. Although we did not study current patterns, we hypothetized that hydrodynamic processes induced by dominant northeasterly winds are prime candidates to explain the spatial heterogeneity in abiotic environmental factors during the spring in Lake of Geneva. In this lake, water circulation is complex, as it is influenced by wind-induced horizontal current, by several river inflows, and by superficial and deep currents flowing in opposite directions (Lemmin 1989). Water temperature and water stability were the highest in the upper part of the great lake (Fig. 3), an area surrounded by mountains. Wind speed patterns during the sampling survey and the previous day (Fig. 1) clearly indicated that the upper great lake was well sheltered from dominant winds. In the small lake and lower and middle great lakes, wind blew at $20 \mathrm{~m} \cdot \mathrm{s}^{-1}$ on the lake, whereas in the upper great lake, winds were stopped by the Jura Mountains and did not blow more than $2.5 \mathrm{~m} \cdot \mathrm{s}^{-1}$. Mountains in the Swiss Jura, which spread on the northeastern side of the lake, thus probably limited the mixing of the surface layer induced by the dominant northeasterly winds during the 
Table 4. Values of correlation coefficients from modified $t$ tests between the environmental variables used as independent variables in the canonical correlation analysis and path analysis models.

\begin{tabular}{|c|c|c|c|c|c|c|c|c|}
\hline & Water stability & $\mathrm{PO}_{4}$ & $\mathrm{NO}_{3}$ & $\mathrm{NH}_{4}$ & $\mathrm{~N} / \mathrm{P}$ & Chlorophyll $a$ & Bacteria & Fish \\
\hline Water temperature & 0.21 & $-0.65^{*}$ & $-0.59 *$ & $0.63 * *$ & 0.50 & $0.71 * *$ & 0.41 & 0.18 \\
\hline Water stability & & -0.34 & $-0.45^{*}$ & 0.15 & 0.19 & 0.34 & -0.08 & 0.29 \\
\hline $\mathrm{PO}_{4}$ & & & 0.41 & $-0.74 *$ & $-0.90 *$ & -0.30 & -0.38 & -0.09 \\
\hline $\mathrm{NH}_{4}$ & & & & & $0.72 *$ & 0.17 & $0.52 *$ & -0.03 \\
\hline $\mathrm{N} / \mathrm{P}$ & & & & & & 0.20 & 0.29 & 0.14 \\
\hline Chlorophyll $a$ & & & & & & & 0.05 & $0.45 * *$ \\
\hline
\end{tabular}

Note: Significance: $* p=0.05 ; * * p=0.01$.

Table 5. Values of correlation coefficients from modified $t$ tests between the environmental variables and the zooplanktonic variables.

\begin{tabular}{|c|c|c|c|c|c|c|c|c|c|}
\hline \multirow[b]{2}{*}{ Zooplankton variable } & \multicolumn{9}{|c|}{ Environmental variable } \\
\hline & $\begin{array}{l}\text { Water } \\
\text { temperature }\end{array}$ & $\begin{array}{l}\text { Water } \\
\text { stability }\end{array}$ & $\mathrm{PO}_{4}$ & $\mathrm{NO}_{3}$ & $\mathrm{NH}_{4}$ & $\mathrm{~N} / \mathrm{P}$ & Chlorophyll $a$ & Bacteria & Fish \\
\hline Eudiaptomus gracilis & $0.64 * *$ & -0.03 & -0.40 & $-0.50 *$ & $0.62 *$ & 0.31 & 0.28 & 0.34 & -0.09 \\
\hline Adults and $\mathrm{C} 4$ and $\mathrm{C} 5$ & $0.55^{*}$ & 0.08 & $-0.40 *$ & $-0.54 *$ & $0.61 *$ & 0.29 & 0.23 & 0.30 & -0.16 \\
\hline Nauplii and $\mathrm{C} 1-\mathrm{C} 3$ & $0.56 * *$ & -0.15 & -0.31 & -0.33 & $0.56^{*}$ & 0.30 & 0.35 & 0.26 & -0.09 \\
\hline Adults and $\mathrm{C} 4$ and $\mathrm{C} 5$ & $0.47 * *$ & 0.07 & $-0.45^{*}$ & -0.17 & $0.52 *$ & $0.39 *$ & 0.19 & $0.40 *$ & -0.15 \\
\hline $\mathrm{C} 2$ and $\mathrm{C} 3$ & 0.20 & -0.11 & 0.00 & 0.07 & 0.06 & -0.02 & 0.19 & -0.06 & 0.02 \\
\hline Cyclops prealpinus & $0.55 * *$ & -0.15 & -0.20 & -0.29 & $0.50 *$ & 0.17 & $0.41 *$ & 0.19 & 0.04 \\
\hline Adults and $\mathrm{C} 4$ and $\mathrm{C} 5$ & 0.35 & -0.08 & -0.21 & -0.26 & 0.34 & 0.12 & 0.15 & 0.15 & -0.21 \\
\hline $\mathrm{C} 2$ and $\mathrm{C} 3$ & $0.55 * *$ & -0.17 & -0.19 & -0.31 & $0.51 *$ & 0.15 & $0.45^{*}$ & 0.19 & 0.11 \\
\hline Daphnia hyalina & $0.41 *$ & 0.11 & -0.17 & $-0.38 *$ & 0.30 & 0.03 & 0.31 & 0.25 & -0.11 \\
\hline Adults & $0.31 *$ & 0.00 & -0.08 & $-0.34 *$ & 0.23 & -0.03 & 0.22 & 0.16 & -0.14 \\
\hline Juveniles & $0.53 *$ & 0.21 & -0.25 & $-0.38 *$ & $0.39 *$ & 0.13 & 0.32 & 0.30 & -0.08 \\
\hline
\end{tabular}

Note: Significance: $* p=0.05 ; * * p=0.01$.

spring season (Lemmin 1989; Angeli et al. 1991). The complex patterns of water circulation, in conjunction with the presence of mountains, may also have contributed to the observed distribution patterns in the case of $\mathrm{NH}_{4}$, chlorophyll $a$, and bacteria that also were more concentrated in the warmer and more stable waters at the northeastern end of the great lake.

\section{Spatial distribution patterns of macrozooplankton}

The distribution of crustaceans in Lake of Geneva showed considerable horizontal variability during spring. Most species and taxa formed large-scale spatial patterns, as observed in several other large lakes (Malone and McQueen 1983; Patalas and Salki 1992; Pinel-Alloul 1995; Stockwell and Sprules 1995). These large-scale patterns may be generated by a variety of vectorial and stochastic-vectorial processes such as currents and upwelling events and by physicochemical alterations caused by river inflows. In Lake of Geneva, the general spatial pattern indicated a greater accumulation of macrozooplankton along the northeastern shore and the upper-lake end of the great lake, which are inflow areas of two major rivers: the Rhône and the Veveyse. Aggregations were also localized in the vicinity of the Venoge and Aubonne inflows, on the north shore, and the Dranse inflow on the south shore (Figs. 1 and 2). The aggregation of macrozooplankton along the northeastern shore of the great lake (Fig. 2) may also be attributed to downwind accumulation due to horizontal advection in this sheltered area. During the spring season, wind speed generally varied from $7.2 \mathrm{~km} \cdot \mathrm{h}^{-1}\left(2 \mathrm{~m} \cdot \mathrm{s}^{-1}\right)$ in sheltered areas to $54 \mathrm{~km} \cdot \mathrm{h}^{-1}\left(15 \mathrm{~m} \cdot \mathrm{s}^{-1}\right)$ in exposed areas (Angeli et al. 1991). Variations in wind intensities between sheltered and exposed areas may have strongly influenced zooplankton distribution in Lake of Geneva. It is recognized that winds and wind-induced currents can break down the spatial structure of plankton. Horizontal advection and redistribution of plankton (Fig. 2) or a downwind accumulation of chlorophyll $a$ (Fig. 3), such as observed in Lake Geneva, may then ensue (Stauffer 1982; Teraguchi et al. 1983; Jones et al. 1995; Lacroix and Lescher-Moutoué 1995).

In Lake of Geneva, despite apparent similarities in the distributions of the different zooplankton taxa (Fig. 2), re- 
Table 6. Results of RDA and partial RDA on taxonomic vectors of total abundances constrained by matrices of environmental and spatial variables.

\begin{tabular}{|c|c|c|c|c|c|}
\hline Vector & $\begin{array}{l}\text { Environmental } \\
\text { variables retained by } \\
\text { forward selection }\end{array}$ & $\begin{array}{l}\% \text { of variance } \\
\text { explained by } \\
\text { environmental variables }\end{array}$ & $\begin{array}{l}\text { Spatial variables } \\
\text { retained by } \\
\text { forward selection }\end{array}$ & $\begin{array}{l}\% \text { of variance } \\
\text { explained by } \\
\text { spatial variables }\end{array}$ & $\begin{array}{l}\% \text { of variance } \\
\text { explained by } \\
\text { each fraction }\end{array}$ \\
\hline Crustacean zooplankton & $\begin{array}{l}\mathrm{NH}_{4} \\
\text { Water temperature } \\
\text { Water stability }\end{array}$ & $\begin{array}{l}80 * * \\
1 * \\
1 *\end{array}$ & $X$ & $60 * *$ & $\begin{array}{l}\text { a: } 41.7 \\
\text { b: } 29.6 \\
\text { c: } 0.3 \\
\text { d: } 28.4\end{array}$ \\
\hline Cyclops vicinus & Water temperature & $49 * *$ & $X$ & $52 *$ & $\begin{array}{l}\text { a: } 21.0 \\
\text { b: } 8.2 \\
\text { c: } 5.8 \\
\text { d: } 65.0\end{array}$ \\
\hline Daphnia hyalina & Water temperature & $69 * *$ & None & & $\begin{array}{l}\text { a: } 0 \\
\text { b: } 37.6 \\
\text { c: } 0 \\
\text { d: } 62.4\end{array}$ \\
\hline Nauplii & $\mathrm{NH}_{4}$ & $78 * *$ & $Y$ & $78 *$ & $\begin{array}{l}\text { a: } 21.0 \\
\text { b: } 24.4 \\
\text { c: } 3.0 \\
\text { d: } 51.6\end{array}$ \\
\hline
\end{tabular}

Note: Significance: ${ }^{*} p=0.05 ; * * p=0.01 . X$, longitude; $Y$, latitude. The percent variance explained was calculated by dividing the proportion of variance within a vector explained by each individual variable by the total variance explained by each set (either environmental or spatial) of factors. Factor: a, nonspatially structured environmental component (local effects); b, spatially structured component (gradient effects); c, residual spatial component; d, undetermined (nonspatial) variation.

Table 7. Results of RDA and partial RDA on vector of total abundances of trophic groups that were constrained by matrices of environmental and spatial variables.

\begin{tabular}{|c|c|c|c|c|c|}
\hline Vector & $\begin{array}{l}\text { Environmental } \\
\text { variables retained by } \\
\text { forward selection }\end{array}$ & $\begin{array}{l}\% \text { of variance explained } \\
\text { by environmental } \\
\text { variables }\end{array}$ & $\begin{array}{l}\text { Spatial variables } \\
\text { retained by } \\
\text { forward selection }\end{array}$ & $\begin{array}{l}\% \text { of variance } \\
\text { explained by } \\
\text { spatial variables }\end{array}$ & $\begin{array}{l}\% \text { of variance } \\
\text { explained by } \\
\text { each fraction }\end{array}$ \\
\hline Young herbivores $^{a}$ & $\begin{array}{l}\mathrm{NH}_{4} \\
\text { Water stability } \\
\text { Chlorophyll } a\end{array}$ & $\begin{array}{l}67 * * \\
16 * \\
15^{*}\end{array}$ & $X$ & $57 *$ & $\begin{array}{l}\text { a: } 45.5 \\
\text { b: } 20.3 \\
\text { c: } 0.1 \\
\text { d: } 34.1\end{array}$ \\
\hline Omnivores/carnivores ${ }^{c}$ & $\mathrm{NH}_{4}$ & $80 * *$ & $\begin{array}{l}X \\
X^{2}\end{array}$ & $\begin{array}{l}60 * * \\
25 *\end{array}$ & $\begin{array}{l}\text { a: } 10.9 \\
\text { b: } 32.2 \\
\text { c: } 2.0 \\
\text { d: } 54.9\end{array}$ \\
\hline
\end{tabular}

Note: Significance: ${ }^{*} p=0.05 ;{ }^{*} p=0.01$. Abbreviations, calculations of percent variance, and factors explained in Table 6 .

${ }^{a}$ Sum of abundances of E. gracilis C1-C3, nauplii, Cyclops spp. C1-C3, and D. hyalina juneviles.

${ }^{b}$ Sum of abundances of E. gracilis adults, C4, and $\mathrm{C} 5$ and D. hyalina adults.

${ }^{c}$ Sum of abundances of Cyclops spp. adults, C5, and C4. 
sults from autocorrelation analyses (Table 3) suggested that spatial patterns varied among crustacean species and trophic groups, as already observed in small lakes. According to Malone and McQueen (1983), horizontal patchiness varies among zooplankton populations; diaptomids tend to form large-scale distribution patterns (type $\mathrm{I}:>1 \mathrm{~km}$ ), whereas cyclopoids exhibit small-scale patterns (type II: 10-1000 m). In our study, the herbivorous E. gracilis, D. hyalina, and the nauplii presented a gradient-like pattern oriented southwest to northeast in the great lake. By contrast, the omnivorous/ carnivorous $C$. vicinus and $C$. prealpinus presented a more patchy distribution. In Lake Créteil, a small shallow sandpit lake in France, cladocerans and calanoids also had similar lake-wide spatial distributions, which were different from the less structured distributions of cyclopoids (Lacroix and Lescher-Moutoué 1995).

\section{Environmental control of the spatial distribution of macrozooplankton}

During spring, the spatial distribution of crustacean zooplankton in Lake of Geneva was mainly driven by abiotic variables (Tables 6 and 7). The distribution of the macrozooplankton was related mostly to water temperature, water stability, and $\mathrm{NH}_{4}$. The distribution of cyclopoids was also related to chlorophyll $a$ biomass and bacteria abundances. Knowing that water temperature and $\mathrm{NH}_{4}$ concentrations were strongly correlated (Table 4), then temperature may be a proximal control variable for macrozooplankton abundances during spring in Lake of Geneva, as suggested by Gawler et al. (1988) and Sommer (1989) for alpine lakes. The direct influence of water temperature could have been through temperature-dependent metabolism and development of zooplankton (Kersting 1978; McLaren and Corkett 1981). In large lakes, temperature and climate are thought to be the proximate factors controlling zooplankton abundances during spring and summer (Patalas 1969; Patalas and Salki 1992; Stockwell and Sprules 1995). If the overall distribution of macrozooplankton was correlated with water temperature, the distribution of each species and trophic group responded in different ways. The effect of water temperature was overall stronger on calanoids (E. gracilis) than on cyclopoids and daphnids (Table 5). This difference in crustacean responses to temperature may be due to the different thermal requirements of the various taxa. Munro (1974) observed that postembryonic development of E. gracilis was strongly temperature dependent, whereas $C$. vicinus, a coldwater species (Maier 1989), was more temperature independent and maintained high growth rates at low temperatures.

Water stability also appeared to have some influence on the distribution of crustaceans, more particularly that of C. prealpinus and young herbivores (Tables 6 and 7). Water stability may have kept phytoplankton in the upper warm and lighted water layers by reducing vertical mixing and enhanced the growth of phytoplankton. These different processes may explain why concentrations of $\mathrm{PO}_{4}$ and $\mathrm{NO}_{3}$, which are nutrients essential to phytoplankton growth, were low where values of water stability, water temperature, and chlorophyll $a$ concentrations were high (Fig. 3; Table 4). The simultaneous development of the spring phytoplankton bloom and marked decreases in $\mathrm{PO}_{4}$ and $\mathrm{NO}_{3}$ concentrations is commonly observed in Lake of Geneva (Balvay et al. 1985). Young herbivores may have concentrated in locations where phytoplankton was abundant, whereas older herbivores may be less dependent on phytoplankton resources.

$\mathrm{NH}_{4}$ concentrations seem to be a good indicator of macrozooplankton aggregation during spring in Lake of Geneva. The proportion of variation explained by $\mathrm{NH}_{4}$ was always high for the different species and trophic groups (Tables 6 and 7). The high correlation values (range of significant values $0.39-0.63$ in Table 5) between zooplankton abundances and $\mathrm{NH}_{4}$ concentrations may be explained by higher excretion of $\mathrm{NH}_{4}$ in the northeastern great lake where macrozooplankton concentrated (Esjmont-Karabin 1985). When $\mathrm{NH}_{4}$ was excluded from the RDA for the crustacean zooplankton, E. gracilis, and older herbivores vectors, there were no additional explanatory variables selected, except for water temperature and (or) water stability, and the total explained variation decreased by $14-40 \%$.

The concentration of chlorophyll $a$ appeared to be positively related to the distribution of the C2 and C3 stages of $C$. prealpinus but not to that of the true herbivores E. gracilis and D. hyalina (Tables 5 and 6). It may be that the distribution of both phytoplankton and $C$. prealpinus $\mathrm{C} 2$ and C3 stages may have been influenced similarly, for example, by wind-induced water currents, whereas other stages were unaffected or affected differently by wind, as shown by Teraguchi et al. (1983) in a freshwater pond. Furthermore, it is unclear how the abundances of older C. vicinus (Table 5) and those of bacteria were linked. The relationship could have been indirect if, for example, the abundances of bacteria reflected the mineralization of fecal matter excreted by copepods, as suggested by the high positive correlation between bacterial abundances and $\mathrm{NH}_{4}$ concentrations.

Fish planktivory is the most likely factor to explain offshore-inshore spatial patterns of zooplankton distribution in large and small lakes (Johannsson et al. 1991; Lacroix and Lescher-Moutoué 1995). In contrast, the absence of relationships between fish biomass and macrozooplankton variables in Lake of Geneva may suggest that fish predation does not affect to any great extent the spatial distribution of crustacean zooplankton during the spring in this large lake. This seems to concur with observations that, at the time of sampling, predation by $R$. rutilus, the dominant species in Lake of Geneva, was probably at its lowest because $R$. rutilus reproduces during spring and may have been less concerned with feeding than reproducing. Furthermore, in mid-April, aquatic insects (mainly Ephemeroptera) have an important contribution to the diet of planktivorous fish (Ponton and Gerdeaux 1988). Another explanation may be that fish and macrozooplankton were sampled at different scales. Macrozooplankton was sampled over a grid at 3- to $5-\mathrm{km}$ intervals, whereas fish biomass was estimated by echosounding in a succession of contiguous 10-min sequences across an 800-m transect.

The unexplained spatial variation (fraction $\mathrm{c}$ in Tables 6 and 7) was relatively small (less than $5.8 \%$ ), except for the vectors E. gracilis and older herbivores (less than 10\%). This spatial component (Borcard and Legendre 1994; Legendre and Legendre 1998), which is due to spatially structured environmental variables or biotic factors that were not measured in this study, had little influence. Thus, we can 
conclude that the large-scale longitudinal gradient of water temperature, water stability, and $\mathrm{NH}_{4}$ and the local smallscale changes in chlorophyll $a$ (fractions a and b) were the most important factors related to the macrozooplankton distribution in Lake of Geneva during the spring. However, the undetermined variation (fraction d in Tables 6 and 7) remained relatively high (28-65\%) and reflects the influence of nonspatially structured (at the sampling scale) environmental factors that were not assessed during our study. For instance, small-scale spatial structures of the biotic variables at a smaller scale may also influence the distribution of zooplankton. A weaker distribution pattern was common to chlorophyll $a$, bacteria, cyclopoids, and nauplii as well as fish biomass, which indicates the existence of spatial structures at scales smaller than the scale (3- to 5 - $\mathrm{km}$ intervals) that we considered in this study.

\section{Acknowledgements}

This research project is part of collaborative program between the GRIL and the Station d'Hydrobiologie lacustre de Thonon-les-Bains. We acknowledge the assistance of French scientist fellows, J.-P. Pelletier for sample collection and pigment analysis, $\mathrm{Ph}$. Dufour for bacteria data, and P. Blanc for chemical analysis. We also are thankful to T. Niyonsenga and G. Méthot for help with the CANOCO program, D.M. Imboden for communicating the program to calculate water stability, and G. Chapuis and J. Barraud for the preparation of the zooplankton subsamples. This work was supported by the Office franco-québécois pour la jeunesse (OFQJ) (travel fund to C. Guay), the Program of France-Québec international cooperation, and NSERC and FCAR team grants to B. Pinel-Alloul.

\section{References}

Amoros, C. 1984. Crustacés cladocères. Bull. Soc. Linn. Lyon, 3: 72-107; 4: 120-144.

Angeli, A., Dufour, P., Gerdeaux, D., Guillard, J., and Pelletier, J.P. 1991. Variabilité horizontale des sels nutritifs et des biomasses planctoniques dans le Léman: incidence de la bise en période de faible stabilité. In Hommage à F.-A. Forel: Troisième conférence internationale des limnologues d'expression française, Morges, Switzerland. Edited by J.-P. Vernet. Forel Institut, Morges, Switzerland. pp. 219-222.

Angeli, N., Pinel-Alloul, B., Balvay, G., and Ménard, I. 1995. Diel patterns of feeding and vertical migration in daphnids and diaptomids during the clear water phase in Lake Geneva (France). Hydrobiologia, 300/301: 163-184.

Balvay, G., Druard, J.-C., Pelletier, J., Pongratz, E., and Revaclier, R. 1984. Plancton. In Le Léman: synthèse 1957-1982. Commission internationale pour la protection des eaux du Léman contre la pollution (CIPEL), Lausanne, Switzerland. pp. 261-303.

Balvay, G., Druart, J.-C., Pelletier, J.-P., and Revaclier, R. 1985. Évolution du plancton du Léman. In Rapports sur les études et recherches entreprises dans le bassin lémanique. Commission internationale pour la protection des eaux du Léman contre la pollution (CIPEL), Lausanne, Switzerland. pp. 49-71.

Bell, G., Lechowicz, M.J., Appenzeller, A., Chandler, M., DeBlois, E., Jackson, L., Mackensie, B., Preziosi, R., Shallenberg, M., and Tinker, N. 1993. The spatial structure of the physical environment. Oecologia, 96: 114-121.
Betsill, R.K., and van den Avyle, M. 1994. Spatial heterogeneity of reservoir zooplankton: a matter of timing? Hydrobiologia, 277: 63-70.

Borcard, D., and Legendre, P. 1994. Environmental control and spatial structure in ecological communities: an example using oribatid mites (Acari, Oribatei). Environ. Ecol. Stat. 1: 37-53.

Borcard, D., Legendre, P., and Drapeau, P. 1992. Partialling out the spatial component of ecological variation. Ecology, 73: 1045-1055.

Carpenter, S. (Editor). 1988. Complex interactions in lake communities. Springer-Verlag, Berlin.

Carpenter, S.R., and Kitchell, J.F. 1993. The trophic cascade in lakes. Cambridge Studies in Ecology. Cambridge University Press, Cambridge, U.K.

Clifford, P., Richardson, S., and Hémon, D. 1989. Assessing the significance of the correlation between two spatial processes. Biometrics, 45: 123-134.

Cressie, N.A.C. 1991. Statistics for spatial data. Wiley, New York.

De Meester, L., Maas, S., Dierckens, K., and Dumont, H.J. 1993. Habitat selection and patchiness in Scapholeberis: horizontal distribution and migration of S. mucronata in a small pond. J. Plankton Res. 15: 1129-1139.

Dussart, B. 1967. Les copépodes des eaux continentales d'Europe occidentale. Tome I: Calanoïdes et harpacticoïdes. Boubée, Paris.

Dussart, B. 1969. Les copépodes des eaux continentales d'Europe occidentale. Tome II: Cyclopoïdes et biologie. Boubée, Paris.

Dutilleul, P. 1993. Modifying the $t$ test for assessing the correlation between two spatial processes. Biometrics, 49: 305-314.

Dutilleul, P., and Legendre, P. 1993. Spatial heterogeneity against heteroscedasticity: an ecological paradigm versus a statistical concept. Oikos, 66: 152-171.

Dutilleul, P., and Pinel-Alloul, B. 1996. A doubly multivariate model for statistical analysis of spatio-temporal environmental data. Environmetrics, 7: 551-566.

Ejsmont-Karabin, J. 1985. Phosphorus and nitrogen excretion by lake zooplankton (rotifers and crustaceans) in relationship to individual body weights of the animals, ambient temperature and presence or absence of food. Ekol. Pol. 32: 3-42.

Flossner, D. 1972. Krebstiere, Crustacea. Kiemen und Blattfusser, Branchiopoda, Fischlause, Branchiura. Die teirwelt Deutschlands, 60.

Gawler, M., Blanc, P., Druart, J.-C., and Pelletier, J.-P. 1986. Dynamique de quelques populations majeures du phytoplancton printanier du lac Léman en relation avec le broutage et les sels nutritifs. Colloq. Natl. CNRS Biol. Popul., Lyon, 4-6 septembre 1986. Université Claude Bernard, Lyon, France. pp. 412-419.

Gawler, M., Balvay, G., Blanc, P., Druart, J.-C., and Pelletier, J.-P. 1988. Plankton ecology of Lake Geneva: a test of the PEGmodel. Arch. Hydrobiol. 114: 161-174.

Geary, R.C. 1954. The contiguity ratio and statistical mapping. Incorp. Stat. 5: 115-145.

Gerdeaux, D., and Guillard, J. 1986. Approche des structures spatio-temporelles des populations de poissons du Léman. Colloq. Natl. CNRS Biol. Popul., Lyon, 4-6 septembre 1986. Université Claude Bernard, Lyon, France. pp. 420-426.

Haining, R. 1990. Spatial data analysis in the social and environmental sciences. Cambridge University Press, Cambridge, U.K.

Haining, R. 1991. Bivariate correlation with spatial data. Geogr. Anal. 23: 210-229.

Hart, R.C. 1990. Zooplankton distribution in relation to turbidity and related environmental gradients in a large subtropical reservoir: patterns and implications. Freshwater Biol. 24: 241-263.

Hastings, A. 1990. Spatial heterogeneity and ecological models. Ecology, 71: 426-428. 
Hobbie, J.E., Daley, R.J., and Jasper, S. 1977. Use of nuclepore filters for counting bacteria by fluorescence microscopy. Appl. Environ. Microbiol. 33: 1225-1228.

Holopainen, A.-L., Huovinen, P., and Huffunen, P. 1993. Horizontal distribution of phytoplankton in two large lakes in eastern Finland. Verh. Int. Ver. Limnol. 25: 557-562.

Imboden, D.M., Eid, B.S.F., Toller, T., Schurter, M., and Wetzel, J. 1979. MELIMEX, an experimental heavy metal pollution study: vertical mixing in a large limno-corral. Schweiz. Z. Hydrol. 41: $177-183$.

Johannsson, O.E., Mills, E.L., and O’Gorman, R. 1991. Changes in the nearshore and offshore zooplankton communities in Lake Ontario: 1981-88. Can. J. Fish. Aquat. Sci. 48: 1546-1557.

Jones, R.I., Fulcher, A.S., Jayakody, J.K.U., Laybourn-Parry, J., Shine, A.J., Watson, M.C., and Young, J.M. 1995. The horizontal distribution of plankton in a deep oligotrophic lake - Loch Ness, Scotland. Freshwater Biol. 33: 161-170.

Kersting, K. 1978. The growth efficiency of Daphnia magna. II. The effect of temperature. Hydrobiol. Bull. 12: 99-106.

Koroleff, F. 1970. Direct determination of ammonia in natural waters as indophenol blue. Information on techniques and methods for seawater analysis. ICES Interlab. Rep. No. 3. pp. 19-22.

Lacroix, G., and Lescher-Moutoué, F. 1995. Spatial patterns of planktonic microcrustaceans in a small shallow lake. Hydrobiologia, 300/301: 205-217.

Legendre, P. 1990. Quantitative methods and biogeographic analysis. In Evolutionary biogeography of the marine algae of the North Atlantic. Edited by D.J. Garbary and R.G. South. NATO ASI Series. Vol. G 22. Springer-Verlag, Berlin.

Legendre, P. 1993. Spatial autocorrelation: trouble or new paradigm? Ecology, 74: 1659-1673.

Legendre, P., and Fortin, M.-J. 1989. Spatial pattern and ecological analysis. Vegetatio, 80: 107-138.

Legendre, P., and Legendre, L. 1998. Numerical ecology. 2nd English ed. Elsevier Science BV, Amsterdam, The Netherlands.

Legendre, P., and Vaudor, A. 1991. The R package: multidimensional analysis, spatial analysis. Département de sciences biologiques, Université de Montréal, Montréal, Qué.

Lemmin, U. 1989. Dynamics of horizontal turbulent mixing in a nearshore zone of Lake of Geneva. Limnol. Oceanogr. 34: 420-434.

Lemmin, U. 1995. Limnologie physique. Chap. 2. In Limnologie générale. Collect. Écol. 25. Edited by R. Pourriot and M. Meybeck. Masson, Paris. pp. 60-114.

MacLennan, D.N., and Simmons, E.J. 1992. Fisheries acoustics. Chapman and Hall, London, U.K.

Maier, G. 1989. The effect of temperature on the development times of eggs, naupliar and copepodite stages of five species of cyclopoid copepods. Hydrobiologia, 184: 79-88.

Malone, B.J., and McQueen, D.J. 1983. Horizontal patchiness in zooplankton populations of two Ontario kettle lakes. Hydrobiologia, 99: 101-124.

Mazumder, A., McQueen, D.J., Taylor, W.D., and Lean, D.R.S. 1988. Effects of fertilization and planktivorous fish (yellow perch) predation on size distribution of particulate phosphorus and assimilated phosphate: large enclosure experiments. Limnol. Oceanogr. 33: 421-430.

McLaren, I.A., and Corkett, C.J. 1981. Temperature-dependent growth and production by a marine copepod. Can. J. Fish. Aquat. Sci. 38: 77-83.

McQueen, D.J., Post, J.R., and Mills, E.L. 1986. Trophic relations in freshwater pelagic ecosystems. Can. J. Fish. Aquat. Sci. 43: 1571-1581.

Megard, R.O., Kuns, M.M., Whiteside, M.C., and Downing, J.A.
1997. Spatial distribution of zooplankton during coastal upwelling in western Lake Superior. Limnol. Oceanogr. 42: 827840.

Monod, R., Blanc, P., and Corvi, C. 1984a. Le régime thermique du Léman. In Le Léman: synthèse 1957-1982. Commission internationale pour la protection des eaux du Léman contre la pollution (CIPEL), Lausanne, Switzerland. pp. 75-88.

Monod R., Blanc, P., Corvi, C., and Revaclier, R. 1984b. Évolution physico-chimique. In Le Léman: synthèse 1957-1982. Commission internationale pour la protection des eaux du Léman contre la pollution (CIPEL), Lausanne, Switzerland. pp. 89-226.

Motoda, S. 1959. Devices of simple plankton apparatus. Mem. Fac. Fish. Hokkaido Univ. 7: 73-94.

Munro, I.G. 1974. The effect of temperature on the development of egg, naupliar and copepodite stages of two species of copepods, Cyclops vicinus Uljanin and Eudiaptomus gracilis Sars. Oecologia, 16: 355-367.

Murphy, J., and Riley, J.P. 1962. A modified single solution method for the determination of phosphate in natural waters. Anal. Chim. Acta, 27: 31-36.

Northcote, T.G. 1988. Fish in the structure and function of freshwater ecosystems: a "top-down" view. Can. J. Fish. Aquat. Sci. 45: 361-379.

Oden, N.L., and Sokal, R.R. 1986. Directional autocorrelation: an extension of spatial correlograms to two dimensions. Syst. Zool. 35: 608-617.

Patalas, K. 1969. Composition and horizontal distribution of crustacean plankton in Lake Ontario. J. Fish. Res. Board Can. 26: 2135-2164.

Patalas, K., and Salki, A. 1992. Crustacean plankton in Lake Winnipeg: variation in space and time as a function of lake morphometry, geology, and climate. Can. J. Fish. Aquat. Sci. 49: 10351059.

Pelletier, J., and Blanc, P. 1991. Sensibilité des lacs aux facteurs climatiques et anthropiques. Exemple d'un grand lac, le Léman. Océanis, 17: 517-529.

Pinel-Alloul, B. 1995. Spatial heterogeneity as a multiscale chartacteristic of zooplankton community. Hydrobiologia, 300/301: $17-42$.

Pinel-Alloul, B., and Pont, D. 1991. Spatial distribution patterns in freshwater macrozooplankton: variation with sampling scales. Can. J. Zool. 69: 1557-1570.

Pinel-Alloul, B., Downing, J.A., Pérusse, M., and Codin-Blumer, G. 1988. Spatial heterogeneity in freshwater zooplankton: systematic variation with body-size, depth and sampling scale. Ecology, 69: 1393-1400.

Pinel-Alloul, B., Méthot, G., Verreault, G., and Vigneault, Y. 1990. Zooplankton species associations in Quebec lakes: variation with abiotic factors, including natural and anthropogenic acidification. Can. J. Fish. Aquat. Sci. 47: 110-121.

Pinel-Alloul, B., Niyonsenga, T., and Legendre, P. 1995. Spatial and environmental components of freshwater zooplankton structure. Ecoscience, 2: 1-19.

Ponton, D., and Gerdeaux, D. 1988. Quelques aspects de l'alimentation de deux poissons planctonophages du Lac Léman: le corégone (Coregonus schinzii palea) et le gardon (Rutilus rutilus L.) Bull. Fr. Piscic. 308: 11-23.

Pourriot, R., Tifnouti, A., and Rougier, R. 1994. Répartition spatiale du zooplancton estival dans un lac de barrage: le Lalla Takerkoust (Maroc). Arch. Hydrobiol. 130: 113-127.

Reynolds, C.S. 1984. The ecology of freshwater phytoplankton. Cambridge University Press, Cambridge, U.K.

Sokal, R.R. 1979. Ecological parameters inferred from spatial correlograms. In Contemporary quantitative ecology and related 
ecometrics. Edited by G.P. Patil and M.L. Rosenzweig. Statistical Ecology Series. Vol. 12. International Co-operative Publ. House, Fairland, Md. pp. 167-196.

Sokal, R.R., and Rohlf, F.J. 1995. Biometry - the principles and practice of statistics in biological research. 3rd ed. W.H. Freeman, New York.

Sommer, U. 1989. Plankton ecology: succession in plankton communities. Brock/Springer Series in Contemporary Bioscience. Springler-Verlag, Berlin.

Stauffer, R.E. 1982. Wind stress effects on chlorophyll distribution in stratified eutrophic lakes. Limnol. Oceanogr. 27: 66-74.

Stockwell, J.D., and Sprules, W.G. 1995. Spatial and temporal patterns of zooplankton biomass in Lake Erie. ICES J. Mar. Sci. 52: $557-564$.

Teraguchi, M., Stucke, D.E., and Noga, M.M. 1983. Spatial dynamics of Mesocyclops edax (S.A. Forbes), Tropocyclops prasinus mexicanus Kiefer, Diaptomus pallidus Herrick, Ceriodaphnia lacustris (Birge), Bosmina longirostris (O.F. Muller), Daphnia parvula (Fordyce) and nauplii in a northeastern Ohio pond. Int. Rev. Gesamten Hydrobiol. 68: 863-883.

ter Braak, C.J.F. 1988. CANOCO - an extension of DECORANA to analyse species-environment relationships. Vegetatio, 75: 159-160. ter Braak, C.J.F. 1990. CANOCO release 3.11. Agricultural Mathematics Group, TNO Institute for Applied Computer Science, Wageningen, The Netherlands.

Tranter, D.J. 1968. Reviews on zooplankton sampling methods. In Zooplankton sampling. Monographs on Oceanographic Methodology. UNESCO, Paris.

Vanni, M.J. 1988. Freshwater zooplankton community structure: introduction of large invertebrate predators and large herbivores to a small-species community. Can. J. Fish. Aquat. Sci. 45: 1758-1770.

Viljanen, M., and Karjalainen, J. 1993. Horizontal distribution of zooplankton in two large lakes in eastern Finland. Verh. Int. Ver. Limnol. 25: 548-551.

Visman, V., McQueen, D.J., and Demers, E. 1994. Zooplankton spatial patterns in two lakes with contrasting fish community structure. Hydrobiologia, 284: 177-191.

Yentsch, C., and Menzel, D. 1963. A method for the determination of phytoplankton chlorophyll and phaeophytin by fluorescence. Deep-Sea Res. 10: 221-231.

Zahner, P. 1984. Géographie physique. In Le Léman: synthèse 1957-1982. Commission internationale pour la protection des eaux du Léman contre la pollution (CIPEL), Lausanne, Switzerland. pp. 35-42. 